\title{
GUIDE TO THE INTERNATIONAL ARCHIVES AND COLLECTIONS AT THE IISH: SUPPLEMENT OVER $1997^{\circ}$
}

The "Guide to the International Archives and Collections at the IISH, Amsterdam" (henceforth cited as GIA), edited by Atie van der Horst and Elly Koen, was first published in 1989. A description of recently acquired archives and collections as well as major accruals to archives received by the IISH will be published annually to keep this survey up to date. From 1994 on a list of microfilms of archives or collections held in other repositories, of which the IISH has received a copy, is added to this survey.

Like the GIA this supplement is subdivided into the categories "persons" and "organizations", arranged alphabetically. The components of each entry are:

I. Access. Restriction is indicated by *.

2. Name. Names of persons include data of birth and death when known.

3. Period. First and last date of the documents present.

4. Size. In linear metres.

5. Entry. Available finding aids.

6. Condensed biography/history.

7. Summary of the contents.

Reference is given to the pages of the GIA holding the initial description where summaries of a supplement are concerned.

Documentary collections are listed separately with only the name, period, size and available finding aids.

For consultation of the archives a written request in advance, addressed to the information service, stating the character of the study, is necessary. Prior request is particularly important because very recently acquired materials may not yet have been arranged or packed.

I. Persons

\section{Abdalla, Ahmed (born 1950) \\ Period: $1978-1983$ (-1990) \\ Size: $0.50 \mathrm{~m}$. \\ Entry: inventory}

Born in Cairo 1950; student leader and publicist; studied political science at Cairo University in the I970s; took his doctor's degree at Cambridge University in 1984; president of the Higher National Committee of Cairo University Students, which led the student uprising in 1972; defendant in the trial of student activists in 1973; during his stay in England active in the Federation of Egyptian Students in Great Britain (FESGB) and member of the Friends of the Tagammu Party in Great Britain.

* Edited by Jaap Haag 
Documents relating to the FESGB I980-1983 and the Friends of the Tagammu ${ }^{c}$ Party in Great Britain 1980-1982; clippings of articles by Ahmed Abdalla published in al- ${ }^{\mathrm{C}}$ Arab 1982-1983; reports, statements, pamphlets, leaflets, copies of periodicals and other printed material concerning the Egyptian student movement, the Communist Party of Egypt (CPE), the Tagammu ${ }^{c}$ Party and other organizations I978-1990.

\section{Domela, Harry (born 1905) \\ Period: (1938-) 1965-1978 (1986) \\ Size: $0.02 \mathrm{~m}$.}

Born in Kurland, Latvia 1905; of German Balt parentage; fought at the age of fifteen in a German volunteer corps against the Latvians; lost his citizenship and joined the beau monde of Potsdam in the I920s; became famous in 1926 by pretending to be the eldest son of the former German crown prince; left Germany c. 1933; lived with false identity papers under the name Victor Zsajka; acquainted with André Gide through the Dutch author Jef Last; in 1936 he served together with Last in the militias of the Spanish Republic; after a stay in Belgium he was interned in VichyFrance; with the help of Gide he managed to leave for Mexico but eventually turned up in Venezuela, where he became a teacher; in 1965 the contact with Jef Last was restored; a letter to Tom Rot dated March 1978 is his last sign of life.

Collection of letters by Harry Domela to Jef Last, consisting of typed copies from the period 1938-1940 and of originals and typed copies from the years 1965-1966 and 1970; copies of letters by Jef Last to Domela 1965; typescript by Jef Last on the life of Domela n.d.; letter by Domela to Tom Rot 1978; copy of a letter from the Dutch Consulate in Maracaibo 1986.

\section{* Gómez Peláez, Fernando (1915-1995)}

\section{Period: c. 1943-1989}

\section{Size: $21.5 \mathrm{~m}$.}

Born in Torrelavega, Spain 1915, died in Fontainebleau, France 1995; journalist and editor; worked for the Santander daily La Región from 1934 until 1936; active in the Unión General de Trabajadores (UGT) in Torrelavega in 1935; militant of the Confederación Nacional del Trabajo (CNT) from the beginning of the Civil War; war correspondent at the front in Burgos; participated in the campaign in Asturias and after a short stay in France in the campaign at the Ebro; took refuge in France in 1939; director of the Solidaridad Obrera in Paris 1946-1954; corrector with a publishing house in Paris from 1954; involved in the publishing of the discussion bulletin Atalaya at the end of the 1950s; director of Frente Libertario, a paper of exiled CNT members 1970-1977; coeditor of Confrontación, the internal bulletin of the Agrupaciones Confederales y Afinidades Libertarias en el Exterior 1977-1982; together with his friend Mariano Aguayo collector of photographs and documents on the Spanish Civil War and from the end of the r950s he worked on a bibliography on the same subject; the memoirs of his youth, entitled "Aquellos años, Torrelavega", remained unpublished.

Collection consisting of circulars, internal bulletins and documents on congresses and meetings of Spanish libertarian organizations and groups in exile, including the Secretariado Intercontinental of the CNT de España en el Exilio, the Federación Anarquista Ibérica (FAI), local and regional organizations and other anarchist groups; letters, including some correspondence with José García Pradas, Cipriano Mera and others in his capacity of editor of Solidaridad Obrera; index cards of his (unpublished) bibliography on the Spanish Civil War; files on various subjects; unpublished manuscripts by others; documents on the CNT and its members both in exile and from 1977 also in Spain. 
Papers of others: documents of Melchor Rodriguez and Pedro Herrera.

Hifni Nasif, Isam al-Din (1899-1969)

Period: 192I-1940 (-1949)

Size: $0.24 \mathrm{~m}$.

Entry: inventory

Born in 1899, died in 1969; Egyptian political activist from Alexandria, publicist and one of the first Egyptian socialist theorists; participated in the nationalist revolt led by the Wafd party in I919; studied agronomy in Berlin I919-I92I and became deeply influenced by German socialist thought and Marxism; because of his criticism not only of British imperialism but also of the Egyptian upper classes he was repeatedly persecuted and tried; founder of the magazine Ruh al- $A s r$ (Spirit of the Age) in 1930 and of the Hizb al- ${ }^{-} U m m a l$ wa al-Fallahin (Party of the Peasants and Workers) in the same year; author of "Al-Mabadi' al-Ishtirakiyya" ("The Principles of Socialism") and other works, including a great many articles in newspapers and magazines, of the novel "Asifa Fawq Misr" ("Storm over Egypt") and of translations of German socialist works.

Collection consisting of clippings of articles and essays by Hifni Nasif on socialism, communism, the Egyptian labour movement, the al-Hizb al-Ishtiraki al-Misri (Egyptian Socialist Party), the Hizb al- ${ }^{c} U m m a l$ wa al-Fallahin, the economic, social, political and cultural situation in Egypt, including the position of the Islam and other subjects I92II940 (-1949); notes by Hifni Nasif; clippings of articles concerning Hifni Nasif and his family and of articles on his trials I924-I938 (-I948).

Humbert, Eugène (1870-1944) and Jeanne Humbert-Rigaudin (I890-1986)

Period: (1863) I889-I986 (-I990)

Size: $0.12 \mathrm{~m}$.

Entry: list

Accrual: for biography see GIA Supplement over 1992, pp. 290-29I.

Eugène Humbert papers: personal documents I889-I9I4; some correspondence I9001943; notes on "Principes de Philosophie Matérialiste" I894; "Lettre ouverte à M. le Sénateur Bérenger", with correspondence I9II.

Jeanne Humbert papers: personal documents 1915-1949; albums with clippings and correspondence relating to her books "En Pleine Vie", "Le Pourrissoir" and "Sous la Cagoule" I930-I934; some other documents 1908-I984.

Papers of others: some correspondence and personal documents of family members I863-I990; letters by Jeanne Humbert to Francis Ronsin (1940) I979-I980.

\author{
Kautsky, Benedikt (1894-I960) \\ Period: 1938-1945 \\ Size: $0.05 \mathrm{~m}$. \\ Accrual: for biography see GIA, p. 83 .
}

Photocopies of correspondence between Benedikt Kautsky and his wife Gerda KautskyBrunn 1938-1945 and some other correspondence 1938-1945.

\title{
Koven, David (born 1918)
}

Period: 1940-1960, 1977-1997

Size: $0.65 \mathrm{~m}$.

Born in Brownsville, Brooklyn, USA I9I8; railroad worker, sailor and electrician; painter and 
photographer; in his youth a member of the Young Communist League; broke with communism and became a pacifist in 1936; turned to anarchism during the Spanish Civil War, when he got involved with the anarchist Vanguard Group; with Audrey Goodfriend one of the founders of Why? (1942-1947), continued as Resistance (1947-1954); moved to San Francisco in the late 1940S, where he became active in Kenneth Rexroth's anarchist group; editor of The Needle in 1956; in I958 with Audrey Goodfriend and three other families cofounder of the libertarian Walden School in Berkeley which still exists; one of the founders of and contributors to Pacific Radio Station and one of the most active members of the Vietnam Day Committee.

Correspondence with anarchists and artists 1940-1960, 1977-1997, including Diva Agostinelli, Paul Avrich, Bob D’Attilio, Howard Ehrlich, Bob Parr, Vernon Richards, Philip Sansom, Nicolas Walter, Colin Ward and David Wieck.

\section{Louis, Roger (1912-1993) \\ Period: (1792) 1827-1896 (-1960) \\ Size: $0.24 \mathrm{~m}$.}

Accrual: for biography see GIA Supplement over 1994, p. 346.

Proof of “L'Espagne et la Liberté" by Ch. de Montalembert I869; photocopies of articles in newspapers and other periodicals, of pamphlets and other publications by or concerning Henri Brissac I850, I855, I887, I896, n.d., Gustave Flourens I864, I898, n.d., Richard Lahautière I839-I840, Albert Laponneraye I835-I842, I848, Pierre Leroux I848, Auguste Rogeard I863-I873, I960, n.d and others I792, I822, I848-1850, I854, I902, I912, I94I; photocopies of newspapers i848; transcriptions of letters by Jules Michelet and his wife I827-I896, n.d.; notes by R. Louis n.d.

\section{Mercier Vega, Louis (I9I4-I977) \\ Period: 1954-1958 \\ Size: $0.01 \mathrm{~m}$.}

Accrual: for biography see GIA, p. II4.

Photocopies of letters by Helmut Rüdiger to Mercier Vega 1954-1958.

NB. Originals at the Centre International de Recherches sur l'Anarchisme (CIRA) in Lausanne, Switzerland.

\section{Mestre Ventura, Ricardo (born I906) \\ Period: 1988}

Size: $0.05 \mathrm{~m}$.

Born in Vilanova i la Geltrú, Catalonia, Spain in 1906; anarcho-syndicalist; construction worker; one of the founders of the Federación Ibérica de Juventudes Libertarias (FIJL); emigrated to Mexico City after the Civil War; cofounder of the Unión Distribuidora de Ediciones.

Transcript of interviews by Enrique Sandoval of reminiscences of his life 1988.

\section{Novikov family}

Period: I917

Size: $0.03 \mathrm{~m}$.

Accrual: for biography see GIA supplement over 1996, p. 34I.

Manuscripts of three numbers of Kolokol'čik, a privately issued journal by E. Novikova and others in Tula I9I7. 


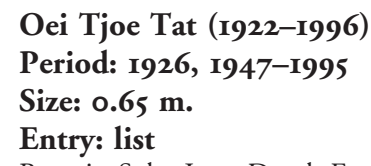

Born in Solo, Java, Dutch East Indies (Indonesia) 1922, died in 1996; politician; graduated at the Universiteit van Indonesië in Batavia (Jakarta) 1948; vice-president of the Partai Demokrat Tionghoa Indonesia (PDTI) in 1953; joined the Badan Permusyawaratan Kewarganegaraan Indonesia (Baperki) in 1954; from 1960 active in the Partai Indonesia (Partindo) and member of its central committee; Minister of State from 1963; detained after the failed coup d'état of 1965 he spent over ten years in prison, not being tried until 1976; released in 1977; his memoirs "Memoar Oei Tjoe Tat: Pembantu Presiden Soekarno" ("The memoirs of Oei Tjoe Tat: President Soekarno's Assistent") were suppressed by the government.

Correspondence, including letters to his wife Rieka Oei, with Daniel S. Lev, W.F. Wertheim and others 1947-1994 and n.d.; diaries and notes 1965, 1977-1978 (-1979), I987 and n.d.; personal documents including documents on his trial in 1976, I940, I947-I994 and n.d.; documents concerning his membership of Baperki I958-I959; documents relating to his work as Minister of State, including minutes of cabinet meetings 1964-1965 and n.d.; typescript and a proof of his memoirs (1974-) 1986-1995; transcriptions of interviews with Oei Tjoe Tat 1987-1993; some printed material 1963-1965, 1979, 1989-1992.

\section{Papanek, Ernst (1900-1973) \\ Period: (1857-) 1900-1995 \\ Size: $4 \mathrm{~m}$. \\ Entry: list}

Pseudonym: Ernst Pek; born in Vienna 1900, died in Vienna 1973; youth leader, pedagogue and education reformer; active in the Verband der Sozialistischen Arbeiterjugend Deutschösterreichs (SAJDÖ) from I919 and its president 1933-1934; member of the City Council of Vienna 19321934; member of the executive committee of the Socialist Youth International (SYI) I934-1939; fled to Czechoslovakia 1934, where he supported the illegal Revolutionäre Sozialistische Jugend (RSJ) in Austria; editor of the International Pedagogical Information (IPI) I936-1938; fled to France 1938; worked for the Organisation de Santé et de l'Education (OSE), which was founded by Russian Jews and smuggled children out of Germany, housing them in castles in France 19381940; fled to the United States 1940; worked for the Children's Aid Society; active in various Austrian emigrant organizations and from 1941 member of the American Socialist Party; in 1945 director of the Child and Youth Project Department of the Unitarian Service Committee (USC) and later director of American Youth for World Youth (AYWY); in 1947 head of the Brooklyn Training School for Girls and from 1949 head of the Wiltwyck School for Boys in New York.

Appointment diaries 1934-1946; files containing correspondence with and other documents concerning family members and friends, including Claude Brown, Alex Goldstern, Ludwig Greve, William Kilpatrick and others 1920-1985 (-1995); identity papers and other personal documents 1900-1973; manuscripts of "Out of the Fire", "The Children of Montmorency", "The Austrian School Reform" and many other publications (1924-) I94I-I97I, n.d.; copies of published articles and documents concerning his publications I942-1971; files on the International Pedagogical Information 1936-1939; on the children's homes of the OSE and the evacution of these children to the USA 1939-194I, with letters and memoirs by former refugee children 1945-1995; on his work for the USC and his role as Child Projects Director in postwar Europe 1946; on his 
work as director of the AYWY 1945-1950; on his school directorship in New York 19491962; on his visits to Israel, Japan and Sweden 1966, 1968; on the Nazi persecution of Austrian Jews and Socialists and the Austrian resistance 1936-1945 (-198I) and files containing correspondence of comrades, including letters by Friedrich Adler, Hugo Breitner, Wilhelm Ellenbogen and Otto Leichter 1940-1945; manuscripts of the (unpublished) autobiography of Helene Papanek-Goldstern and transcripts of interviews with her 1978-I979.

\section{Schmalhausen, Caroline (1846-1927) \\ Period: 1867 \\ Size: $0.01 \mathrm{~m}$.}

Born in Maastricht, the Netherlands 1846, died in Bussum, the Netherlands 1927; daughter of Sophie Schmalhausen-Marx (I8I6-I886), who was an elder sister of Karl Marx.

Letters to Caroline Schmalhausen by her mother Sophie Schmalhausen-Marx, her sister Bertha and her brother Benno I867.

\section{* Schmidt, Lissy (Elisabeth) (1959-1994) \\ Period: 1982-1994}

\section{Size: $2 \mathrm{~m}$.}

Pseudonym: Milena Ergen and Petra Sert; born in Germany 1959, died near Suleymania, Iraq 1994; journalist; participated in the catholic peace movement Pax Christi and joined the campaign against the stationing of cruise missiles in Europe; moved to Istanbul 1984; published on Turkish issues; sympathized with the Kurds and their struggle for freedom; worked in the Turkish part of Kurdistan and after the Gulf War also in the autonomous Kurdish region in North-Iraq; visited Kirkuk in disguise in 199I; arrested and expelled by the Iraqi authorities and in 1992 also expelled by Turkey; worked alternately in the autonomous Kurdish region and in Frankfurt am Main 199I-1994; contributed to the Frankfurter Rundschau, the Tageszeitung and other periodicals and to radioprograms; shot near Suleymania on 3 April 1994 together with her Kurdish guide Aziz Quadir Faraj.

Documents, including letters, notes, reports, pamphlets and clippings on the agitation against the stationing of cruise missiles in Europe and against the extension of the Frankfurt airport 1982-1984; on the Turkish trade union movement, the position of women, medical care and other subjects relating to Turkey 1985-1990; on the Kurds and their struggle for liberation, including documents on the actions by the Turkish army 1988-1990; on the deportations of Kurds, the bombing of their dwellings and the use of chemical weapons against the village of Halabja by the army of Iraq 1989-1990; on the aid organization medico international 1988-1990; on the uprising in Iraqi Kurdistan in 1991, the subsequent elections in 1992 and on the Democratic Party of Kurdistan (PDK) of Massoud Barzani and its IIth Congress in I993; documents relating to agitation for the release of the German journalist Stephan Waldberg, imprisoned in Turkey because of his supposed support of the Partîya Karkerên Kurdîstan (PKK; Kurdish Workers' Party) 1992-1994; press clippings and other documents regarding the death of Lissy Schmidt and the arrest of two suspected murderers 1994; typescripts and manuscripts of articles and translations by Lissy Schmidt and clippings of her articles 19841994; a typescript on economic problems in Iraqi Kurdistan by Salahaddin Muhammad al-Hafid 1992; text of an interview with Celal Talabani, general secretary of the Patriotic Union of Kurdistan (PUK) n.d. 


\author{
Seiwert, Franz Wilhelm (1894-1933) \\ Period: 1919-1923, 1933, 1977-1978 \\ Size: $0.12 \mathrm{~m}$. \\ Entry: list
}

Born in Cologne, Germany I894, died in Cologne 1933; graphic artist, painter and sculptor; participated in the Gruppe Progressiver Künstler in Cologne; member of the Anti-Kriegs-Kreis; published graphic work for the first time in 1917 in Die Aktion; cofounder of the Cologne section of the Berliner Arbeitsrat für Kunst in 19I8; in contact with Dadaists; published political articles in Die Aktion, Sozialistische Republik and Die Revolution; member of the radical left Allgemeine Arbeiter-Union, Einheitsorganisation (AAUE) in 1920; friend of Gerd Arntz from 1920 and from 1922 he also came into contact with Constantin Brancusi, Theo van Doesburg, Fernand Léger, El Lissitzky, Lazlo Moholy-Nagy, August Sander and Kurt Schwitters; wrote many reviews and articles on art and architecture under the pseudonym Rogkerus from 1927.

Collection from the legacy of Gerd Arntz consisting of manuscripts of articles and letters by Seiwert c. 1919-1923; Seiwert's last postcard to Brecht Alma 1933; letters from Gerd Arntz, Lazlo Moholy-Nagy, Piet Mondriaan and others to Hans Schmitt-Rost on the death of Seiwert 1933; file on the conflict about the legacy of Seiwert 1977-1978.

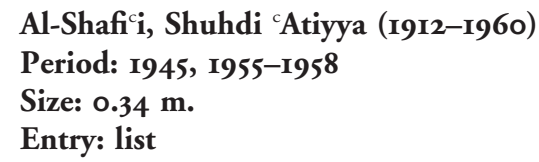

Born in I9I2, died in Cairo 1960; communist and publicist; studied literature; took his masters degree at Cambridge University; returned to Egypt during the Second World War; one of the founders of the Dar al-Abhath al-'Ilmiyya (Scientific Research Council), which attracted many left-wing intellectuals; within the Egyptian communist movement Shuhdi 'Atiyya belonged to the Iskra group and was one of the authors of its programme; involved in the student and workers' revolt against the British domination of Egypt in 1946; editor of the communist newspaper alJamahir (The Masses) from 1947; in 1948 sentenced to a seven years prison term; in the 1950s he supported a rapprochement with the regime of the Free Officers of Gamal Abd al-Nasir because of its policy of land reform, nationalizations and anti-imperialism, which reached its summit during the Suez crisis in 1956; in 1958, however, the unification of Egypt with Syria strained the cooperation with the Nasserist regime; with hundreds of other communists Shuhdi 'Atiyya was arrested in 1959 and sentenced in 1960; he died under torture in the Abu Zacbal prison in the same year; his publications include "Amrika wa-l-Sharq al-Awsat" ("America and the Middle East") 1955 and "Tatawwur al-Haraka al Wataniyya al-Misriyya I882-1956" ("The Development of the Egyptian Nationalist Movement, I882-1956") 1957, which is one of the most penetrating Marxist interpretations of Egyptian history.

Parts of the manuscript of "Tatawwur al-Haraka al Wataniyya al-Misriyya I882-1956"; manuscripts of short stories; typewritten notes and printed source material used for different books; copy of the Iskra group programme "Ahdafuna al-Wataniyya" ("Our National Goals") I945.

\title{
Škrábek, Karel (born 1919) \\ Period: [191I-] 1952-1997
}

Size: $\mathbf{1 . 7 5}$

Accrual: for biography see GIA Supplement over 1990, p. 320.

Documents concerning the Konfederace Politických Vežñu (KPV, Confederation of 
political prisoners), consisting of minutes of meetings of its board and its council 1992I996; minutes of meetings and other documents of its agricultural committee, including documents on the restitution of confiscated land; documents of the KPV Plzen branch and some correspondence; documents relating to the Česká Strana Sociálně Demokratická (ČSSD, Czech Social Democratic Party) 1989-1996, including (draft) party manifestos, rules, documents concerning congresses and some correspondence; minutes of meetings of the CSSD historical committee; circulars, electoral programmes, leaflets and other documents of the ČSSD Plzeň branch; photocopies of Naše Cesta, edited by Škrabek (under the pen name Karel Sova) and other young social democrats in exile 1952, 1954, I955; files on the persecution of social democrats after 1948; some biographical material on Škrábek.

Documents collected by Škrábek, including notebooks with extracts by J.J. Šmid and others [I9II], I9I6-I9I8 and n.d. and a scrap-book by J. Hošek, who fought in the Spanish Civil War; clippings, photocopies of books and articles, and other documentation on the international brigades in the Spanish Civil War, the Komunistička Strana Československa (KSČ , Communist Party of Czechoslovakia), the anti-communist resistance 1948-1989, the Prague Spring 1968-1969, Charta 1977, the political development in Czechoslovakia after November 1989 and many other subjects.

\section{Vâ-Nû, Vâlâ Nûreddin (I90I-1967) \\ Period: c. 1930-1960 \\ Size: c. $1.50 \mathrm{~m}$.}

Born in Istanbul 190I, died in Istanbul 1967; journalist and writer; educated at the French-speaking Galatasaray Lyceum in Istanbul and in 1917 at the Vienna School of Economics; after his return to Turkey he became a teacher in Bolu; left for Moscow, together with Nazım Hikmet, in I92I; graduated at the Kommunističeskij Universitet Trudjašcichsja Vostoka (Communist University of the Workers of the East) in 1925; returned to Turkey in 1928; contributed to the newspapers Akşam (Evening) and Cumburiyet (Republic) with columns, reviews, polemics and reports; in later years, together with Rasim Us, editor of the newspaper Haber (News); author of novels and short stories (under the pseudonyms Hatice Süreyya, Ali Marmara and other names) and of "Bu Dünyadan Nazım Geçti”, his reminiscences of Nazım Hikmet, published in 1965; Vâ-Nû was married to the novelist Müzehher Vâ-Nû (born in I9I2).

Letters (partly in old Turkish handwriting) to Vâ-Nû and his wife Müzehher Vâ-Nû by Sevket Süreyya Aydemir c. 1965-1977, Nazım Hikmet c. 1930-1950, Zekeriya Sertel c. 1948-1977 and others; personal documents, including identity cards and passports of Vâlâ Nûreddin and Müzehher Vâ-Nû; manuscript of Vâ-Nû's "Kibar Hırsız" and manuscripts by Müzehher Vâ-Nû (written under the pseudonym of Nihal Karamağrali), including "Lodoslu Ada", "Inci Tesbihler" and "Mirasçılar"; clippings of their articles; printed material concerning Nazım Hikmet.

\section{Organizations}

\section{Arbeitskreis Wesermarsch (AkW) \\ Period: 1982-1992 \\ Size: $0.12 \mathrm{~m}$. \\ Entry: list}

The Arbeitskreis Wesermarsch, Regionalkonferenz der Bürgerinitiativen Umweltschutz (AkW) was founded c. 1982 during the campaign against the stationing of USA Pershing and cruise 
missiles in West Germany; in the AkW various action groups from the German Weser-Ems region campaigned for disarmament and environmental protection and the resistance against nuclear energy.

Reports of meetings of the AkW I983-199I; pamphlets, press statements, clippings, some correspondence and other documents on harbour blockades in Bremerhafen and Nordenham and on actions to stop US munition and nuclear transports by train $1983-$ I989; on demonstrations near nuclear plants, including the power station in Esenshamm in 1984; on protests against NATO exercises in 1987; on police actions and other measures taken by the authorities against the peace and anti-nuclear movements 1982-1992.

\section{Communist Party of India (Marxist-Leninist) (CPI (M-L)) \\ Period: 1963-1972, 1977, 1997 \\ Size: $0.04 \mathrm{~m}$.}

Founded in the late 1960s; major Maoist party of India; because of its association with the rural uprising in the Naxalbari region of West Bengal the followers of the CPI (M-L) became also known as "Naxalites"; its charismatic leader was Charu Majumdar, who died in 1972.

Collection consisting of a notebook of Rabindranath Dey containing his notes of 69 speeches by Charu Majumdar and of some texts by Charu Majumdar 1965-1972; documents on the commemoration of the 25th death anniversary of Charu Majumdar 1997; photocopies of some letters from prison by Charu Majumdar to his wife Lila 1963, 19651966; leaflet 1996; text of a resolution by the Andhra Pradesh State Committee of the CPI (M-L) I977; offprint of “The Peoples' Movement in Hyderabad I920-I947” by Raj Bahadur Gour n.d.; leaflets of the CPI (M-L)-New Democracy in West Bengal 1997.

\section{Communist Party of Sudan (CPS)}

NB. See al-Hizb al-Shuyuci al-Sudani

\section{Gruppe Fasten für das Leben \\ Period: 1983}

Size: $2.00 \mathrm{~m}$.

Originated from a hunger strike in 1983 in Bonn, Germany, by participants of a non-violent campaign for disarmament and against nuclear weapons; its example led to similar hunger strikes in East Berlin, Paris, San Francisco and other cities in West Germany.

Collection of documents concerning the hunger strikes, including papers of Johanna Jordan, who was one of the participants; correspondence and letters of support; leaflets of and other printed material concerning the group and the campaign Fasten für das Leben and printed material concerning the peace movement in general.

\section{Al-Hizb al-Shuyu'i al-Sudani Period: (1960-) 1969-1985 (-1996) \\ Size: $0.50 \mathrm{~m}$. \\ Entry: list}

Founded in 1946 as the Sudanese Movement for National Liberation (SMNL); supported the struggle for national independence, gained by the Sudan in 1956 , after which the SMNL changed its name into al-Hizb al-Shuyu 'i al-Sudani (Communist Party of Sudan, CPS); founder of the Sudan Workers' Trade Union Federation (SWTUF) in I950; had strong ties with the organizations of railway workers and cotton growers; recruiting its members among workers, students and new professionals, the party 
remained a rather weak political factor; joined the Front of Opposition Parties (FOP) against the military regime of 1958, which was brought down by the October revolution of 1964; in 1967 the Muslim Brotherhood succeeded in having the CPS outlawed as an atheist organization; re-established itself as Socialist Party of the Sudan; divided on its position towards the Free Officers of Jacfar alNimeiri, who took power in 1969; after the failure of a counter coup d'état by communist officers in I97I the party was outlawed again and its leader Abd al-Khaliq Mahjub executed; continuing its activities underground the CPS did not regain its legal status until 1985; after the military takeover of 1989 the CPS, banned once again, joined the National Democratic Alliance, which works for democracy and autonomy of the south of the Sudan.

Collection of documents consisting of published reports of meetings of the central committee of the party 1963, 1969-1987; leaflets, pamphlets and other publications by the CPS 1960, 1964, 1968-1985 (-1996); copies of al-Midan 1972-1984, I989-1990; publications by the CPS student organization 1973-1985 (-1989); publications by trade unions 1964, 1973-1985; pamphlets, leaflets and petitions by the CPS for the release of prisoners 1973-1985; pamphlets, leaflets and other publications by sections of the CPS in Europe and the Soviet Union 1965, 1971-1984.

\section{* Hizb al-Tagammu ${ }^{c}$ \\ Period: (1970-) 1976-1993 \\ Size: $\mathbf{I} .88 \mathrm{~m}$. \\ Entry: inventory}

Founded in 1976 the Egyptian Hizb al-Tagammu ${ }^{c}$ al-Watani al-Taqaddumi al-Wahdawi (National Progressive Unionist Party), or briefly Hizb al-Tagammuc, constituted the platform of the left in the period of political liberalization under president Anwar al-Sadat; Marxists, former Free Officers and Arab nationalists joined the party, which defended the Nasserist programme of the planned economy and social welfare; it became one of the main political opponents of Sadat during the last years of his presidency, criticizing the Camp David Accords, the Open Door policy and the increasingly repressive political climate; during the general elections of 1976 the Tagammu ${ }^{c}$ party won three seats (out of 350); its membership, however, increased to I50,000; after the food riots of 1977 the party's activities were obstructed by the government, and its organ al-Ahali (the People) was closed down in 1978; under Mubarak the party regained its strength, to decline again during the second half of the i98os.

Documents collected by Bertus Hendriks.

Proposals for a party programme and other documents relating to the founding of the Tagammuc Party 1976-1978; resolutions, some proceedings and other documents relating to meetings of the Central Committee 1979-199I; resolutions, communiqués and other documents relating to congresses 1979-1992; statutes 1979-1982; reports of founding meetings of branches in Alexandria, Asyut, Cairo, Suez and other cities or regions 1978-198I; documents concerning election campaigns 1976-1987; pamphlets, leaflets and statements concerning Egyptian political issues 1977-198I, I9901992; documents relating to the Maktab al-'Ummal al-Markazi (Central Workers' Bureau), the Ittihad al-Fallahin al-Misriyyin (Federation of Egyptian Peasants), the Ittihad al-Nisa ${ }^{c}$ al Taqadumi (Progressive Federation for Women) and other affiliated organizations 1976-1986; copies of al Taqaddum and other periodicals and of publications for cadre training 1976-1993; documents on the Tagammu ${ }^{\mathrm{c}}$ Party consisting of notes by Bertus Hendriks, pamphlets, photocopies of articles and clippings 1970I988. 


\author{
* Indonesian exiles of the left \\ Period: 1923, I947-1996 \\ Size: c. $0.50 \mathrm{~m}$. \\ Entry: list
}

The oral history project "In Search of Silenced Voices" was started in 1996; its objective is to record the experiences of left-wing Indonesians, who lived in exile after the military took power in 1965; the interviews cover the period before 1965 and the experiences of their exile in Europe, China and Vietnam since 1965.

Collection of letters, reports, memoirs and documentation of Indonesian exiles concerning the Indonesian left, including the Lekra (People's Culture League), the trade union movement the Partai Komunis Indonesia (PKI; Communist Party of Indonesia) and other organizations, acquired as part of the oral history project "In Search of Silenced Voices".

\title{
International Transport Workers' Federation (ITF) \\ Period: 1995, 1997 \\ Size: $0.03 \mathrm{~m}$.
}

Accrual: see GIA, p. 254 and GIA supplement over 1996, p. 345.

File on the Dockers' Section Conference in Miami 1997.

\section{London Federation of Anarchists \\ Period: (I96I-) 1963}

\section{Size: $0.12 \mathrm{~m}$.}

Accrual: for biography see GIA supplement over 1994, p. 350.

General correspondence, with some receipts and financial notes (I96I-) I963; some printed material.

\section{* Nationalist movement in Arakan \\ Period: $1987-1996$ \\ Size: $0.04 \mathrm{~m}$.}

In Arakan, a federated state of Burma (Myanmar), a number of oppositional and nationalist groups are active, many of them seeking independence.

Collection consisting of some documents of the National United Party of Arakan 1995; election manifesto by the Arakan League for Democracy 1990; copy of the pamphlet "The Voice of Rakhine", published by the exiled Rakhine Student Organization of Bangladesh 1987 and some other documents.

\section{Neues Forum}

\section{Period: 1989-1995}

\section{Size: I.I2 m.}

\section{Entry: list}

Founded in September 1989, Neues Forum was the most prominent opposition group during the overthrow of the communist regime in the German Democratic Republic (GDR) in 1989; after the "Wende" in November 1989 it was a civic movement in the eastern part of the newly united Germany until 1994; Bernd Florath was a member of its Republiksprecherrat (federal council of spokesmen) from 1990 to 1993 . 
Collection of documents of Bernd Florath.

Some documents of Neues Forum, Böhlener Plattform and other oppositional groups from the period before the "Wende" in 1989; documents from the period after November 1989: minutes of meetings of federal and regional bodies of Neues Forum and of related groups; circular letters and some correspondence; discussion and policy papers on a democratic reshaping of the GDR, on constitutional reforms towards direct civic participation in a united Germany and the Neues Forum's entering of the existing representative system; documents concerning election alliances and campaigns; statutes and other documents on its organization; documents from other organizations, including Initiative Frieden und Menschenrechte, Vereinigte Linke, Demokratie Jetzt, Grüne Partei, Grüne Liga and Bündnis '9o; bulletins, copies of other periodicals, public statements, leaflets, clippings and other printed material on the right of asylum, conscription, the old and new secret police, racism and neo-Fascism, the Gulf and Yugoslav wars and other subjects.

\section{Organizing Committee Chittagong Hill Tracts Campaign (OCCHTC) Period: 1977-1996 \\ Size: 2 m.}

The Chittagong Hill Tracts in the south-east of Bangladesh are inhabitated by several ethnic groups which are often referred to collectively as "Jumma"; from the I970s armed resistance to the Bangladesh government, which was organized by the liberation organization Jana Samhati Samiti (JSS, United Peoples Party; its official name is Parbatya Chattagram Jana Samhati Samiti, United Peoples Party of the Chittagong Hill Tracts), resulted in extensive militarization of the region; the movement for Jumma self-determination has been supported by an international campaign, coordinated by the OCCHTC; this committee was founded in Amsterdam in 1986 at an international conference on human rights violations in the Chittagong Hill Tracts; an Information Network was founded in Copenhagen at the office of the International Work Group for Indigenous Affairs (IWGIA).

Collection of the OCCHTC consisting of reports and publications by the PCJSS and its armed wing, the Santi Bahini (SB); copies of proceedings of the dialogue between the Bangladesh government and the (PC)JSS; reports on human rights violations by the Bangladesh armed forces; printed and processed materials on Jumma refugees in India; press releases, statements, reports, newsletters and other documents of various Jumma organizations, including the Chittagong Hill Tracts Jumma Refugees Welfare Association, the Hill People's Council, the Hill Students' Council, the Hill Watch Human Rights Forum, the Hill Women's Council and the Jumma People's Network; reports by the Chittagong Hill Tracts Commission, Amnesty International, Anti-Slavery Society, Survival International, United Nations and other international organizations; publications by Bengali settler organizations; press clippings.

\section{Progressive movements in Pakistan \\ Period: 1922-1997}

\section{Size: $0.24 \mathrm{~m}$.}

Progressive movements emerged during the colonial rule of the former British India and continued after the Partition in 1947, when Pakistan became independent.

Documents concerning progressive movements in Pakistan collected by Ahmad Saleem of the Gohar Research Institute of Pakistan (GRIP) in Lahore.

Some reports, pamphlets, copies of periodicals, clippings and other documents of the 
Communist Party of Pakistan, the Pakistan National Awami Party and other parties 1940-1997; documents concerning students I982-1986; some files on conspiracy cases against communists 1922, 1924, 1927; copies of periodicals and clippings, including cartoons 1948-1956, I975.

\section{* Solidarité}

Period: $1966-1967$

Size: $0.01 \mathrm{~m}$.

Entry:

Accrual: for biography see GIA supplement over 1995, p. 292.

Documents relating to the relief action for victims of the civil war in the Dominican Republic.

Tagammuc Party

NB. See Hizb al-Tagammu ${ }^{c}$

\section{* War Resisters' International (WRI)}

Period: 1949-1993

Size: $2.65 \mathrm{~m}$.

Entry: list

Accrual: for biography see GIA, pp. 240-24I.

Additional records from the period 1949-1993.

\section{World Crafts Council}

Period: $1985-1993$

Size: $0.65 \mathrm{~m}$.

Accrual: for biography see GIA supplement over 1990, p. 323.

Additional records 1977-1993.

\section{Documentation collections}

\section{Communist Party of India (CPI)}

1946, 1948; $0.02 \mathrm{~m}$.

Coordination Nationale d'Associations pour le Droit à l'Avortement et à la Contraception (CADAC) and Collectif national pour les droits des femmes 1991, 1994-1998; $0.04 \mathrm{~m}$.

\section{Human rights and social developments in Turkey}

Accrual: 1991-1994; $0.35 \mathrm{~m}$.

\section{Israeli peace movement}

Accrual: 1990s; $7 \mathrm{~m}$.

Mandi (Garo)

Accrual: 1980-1982, I988-1997; 0.18 m.; list 
4. Films and microfiches

\section{Central'noe Bjuro Zagraničnych Grupp (CBZG) RSDRP}

I908-I9I4; 39 reels; inventory

NB. Originals at the Rossijskij Centr Chranenija i Izučenija Dokumentov Novejšej Istorii (RCChIDNI) in Moscow, fund 276.

\section{Central'nyj Komitet RSDRP (internacionalistov)}

I917-I920; 3 reels; inventory

NB. Originals at the RCChIDNI in Moscow, fund 444.

\section{Central'nyj Komitet RSDRP (men'ševikov)}

I9I7-I923; 9 reels; inventory

NB. Originals at the RCChIDNI in Moscow, fund 275.

Dittmann, Wilhelm (1874-1954)

Accrual: 62 reels

NB Originals at the RCChIDNI in Moscow, fund 215.

\section{Iranian political and social movements}

c. 1950-1997; I2 reels; list

NB. Originals at the Centre Iranien de Documentation et de Recherche in Paris.

Redakcija gazety Golos Social-Demokrata i gazety Listok Golosa Social-Demokrata 1907-I9I4; 2 reels; inventory

NB. Originals at the RCChIDNI in Moscow, fund 34I.

\section{Redakcija gazety Social-Demokrat}

1908-1917; 3 reels; inventory

NB. Originals at the RCChIDNI in Moscow, fund 28.

\section{Vozvraščenie}

4 reels; superscriptions

NB. Originals at the historical literary society Vozvraščenie in Moscow. 